\author{
Dorian CZARNIECKI ${ }^{1}$ \\ Daniel SŁYŚ
}

\title{
ANALIZA TECHNICZNA I FINANSOWA SUSZENIA SKÓR PRZY UŻYCIU POMPY CIEPŁA Z ZASTOSOWANIEM RÓŻNYCH DOLNYCH ŹRÓDEL CIEPŁA
}

\begin{abstract}
Skóra zwierząt zalicza się do jednego z pierwszych surowców stosowanych przez człowieka. Początkowo używane były skóry w nieprzetworzonej formie. Działanie wilgoci, pleśni oraz bakterii skutkowało szybkim zniszczeniem wyrobów wykonanych z nieprzetworzonej skóry. Z upływem lat człowiek nauczył się w jaki sposób wydłużyć trwałość, podnieść wytrzymałość mechaniczną oraz zwiększyć walory estetyczne skóry. Wyprawiona skóra stała się wszechstronnym materiałem o ogromnym znaczeniu dla rozwoju cywilizacji. Ze skóry upolowanych zwierząt wytwarzane były przede wszystkim przedmioty codziennego użytku, tj. obuwie, odzież, torby, namioty, uprzęże dla zwierząt pociągowych, księgi, elementy zbroi i broni itp. Wraz z rozwojem technicznym skóra znajdowała coraz szersze zastosowanie. W ostatnim wieku można zaobserwować tendencje do wypierania skóry jako materiału technicznego przez gumę, tworzywa sztuczne oraz tworzywa skóropodobne. Ogólnoświatowe trendy wykazują jednak, że wyprawiona skóra jeszcze długo będzie luksusowym i poszukiwanym materiałem do produkcji obuwia, odzieży, wyrobów kaletniczych, etc. Poznanie i opanowanie procesu garbowania umożliwiło udział wyrobów skórzanych w codziennym życiu człowieka. Technika garbowania skóry jest niezwykle złożona, składa się z wielu procesów i operacji technologicznych, w których bardzo ważną rolę pełni suszenie. Celem niniejszego artykułu jest porównanie systemów wykorzystania alternatywnych źródeł energii przy użyciu pompy ciepła, w celu zaopatrzenia w ciepło nagrzewnicy powietrza w procesie suszenia skór. Przeprowadzono wielowariantową analizę techniczną i finansową tych układów w ustalonych uwarunkowaniach. Instalację dla suszarni tunelowej przeanalizowano dla pięciu wariantów.
\end{abstract}

\footnotetext{
${ }^{1}$ Autor do korespondencji / corresponding author: Dorian Czarniecki, Politechnika Rzeszowska, Wydział Budownictwa, Inżynierii Środowiska i Architektury, Zakład Infrastruktury i Ekorozwoju, al. Powstańców Warszawy 6, 35-959 Rzeszów, tel. +48 177432409 , e-mail: doriancz@prz.edu.pl

2 Daniel Słyś, Politechnika Rzeszowska, Wydział Budownictwa, Inżynierii Środowiska i Architektury, Zakład Infrastruktury i Ekorozwoju, al. Powstańców Warszawy 6, 35-959 Rzeszów, tel. +48 17 8651784, e-mail: daniels@ @rz.edu.pl
} 
Słowa kluczowe: pompa ciepła, dolne źródło ciepła, gruntowy wymiennik ciepła, ciepło odpadowe, ścieki garbarskie

\section{Wprowadzenie}

Garbowanie jest procesem wyprawy skóry, przekształcającym odpowiednio przygotowaną surową skórę w wyprawioną, charakteryzującą się nowymi lepszymi własnościami użytkowymi. Istotną funkcję w całym procesie pełnią operacje wykończeniowe, podzielone na wykańczanie kąpielowe (mokre) oraz wykańczanie właściwe. Celem wspomnianych etapów jest podniesienie walorów użytkowych oraz nadanie pożądanego wyglądu skórom po wygarbowaniu. Technika tych procesów jest niezwykle złożona, składa się bowiem z wielu procesów oraz operacji technologicznych, których nieodłącznym elementem jest suszenie $[1,6,18]$.

Suszenie jest niezwykle energochłonnym procesem cieplnym polegającym na uwalnianiu materiałów stałych lub roztworów od zawartej w nich wody przez jej odparowanie [11]. Jest to jeden z najbardziej rozpowszechnionych procesów, mający szerokie zastosowanie w różnych gałęziach przemysłu, m.in. chemicznego, spożywczego, garbarskiego, włókienniczego, ceramicznego, samochodowego, budowlanego, itp.

Procesowi suszenia poddawane są ciała wilgotne charakteryzujące się różnymi właściwościami fizyko-chemicznymi, strukturalno-mechanicznymi, biochemicznymi i innymi [22]. Rozróżniane są następujące typy materiałów suszonych [22]:

- ciała typowo koloidalne - podczas suszenia zmieniają swoje wymiary liniowe, zaczynają się kurczyć, zachowując przy tym właściwości ciał elastycznych, np. żelatyna, agar,

- ciała kapilarno-porowate - w trakcie suszenia stają się kruche, mogą przekształcać się w proszek, np. materiały ceramiczne, węgiel drzewny,

- ciała kapilarno-porowate koloidalne - ciała te posiadają cechy wymienionych wcześniej grup; w trakcie suszenia w wyniku pochłaniania wilgoci ścianki kapilar pęcznieją, zachowując przy tym elastyczność, np. skóra, drewno, glina.

Skóry są ciałami stałymi pochodzenia organicznego. W tego typu materiałach wilgoć stanowi nierozerwalną część struktury ciała stałego lub zamknięta jest we włóknach oraz drobnych porach wewnętrznych. Ruch wilgoci jest w tym przypadku powolny i odbywa się na zasadzie dyfuzji cieczy przez wewnętrzną strukturę ciała [22].

Idea zrównoważonego rozwoju kładzie nacisk na poszukiwanie nowych rozwiązań systemów zaopatrzenia w ciepło, takich jak rozwój niskoemisyjnych technologii wytwarzania energii - zwłaszcza ze źródeł odnawialnych czy odpadowych oraz poprawa sprawności wytwarzania energii $[2,20]$. Odpowiedzią na 
taki trend jest wykorzystanie niskotemperaturowych źródeł energii przy użyciu pompy ciepła.

\section{Warianty rozwiązań systemu suszenia skór $\mathrm{z}$ zastosowaniem pompy ciepła $\mathrm{z}$ uwzględnieniem różnych dolnych źródeł ciepła}

W tradycyjnych suszarniach podgrzewanie strumienia powietrza realizowane jest w nagrzewnicach elektrycznych, kotłach gazowych oraz na paliwo stałe. Biorąc pod uwagę rosnące zapotrzebowanie na energię rozpatruje się różne niekonwencjonalne metody jej uzyskiwania, stąd do tego celu mogą być również wykorzystywane instalacje z pompami ciepła. Zwłaszcza w przypadku dużych garbarń szczególnie widoczne jest duże zainteresowanie możliwościami ich zastosowania, co jest całkowicie zgodne z ideą Czystej Produkcji. Profesjonalne doradztwo w tej dziedzinie powinno stanowić w najbliższych latach istotny element działalności każdej organizacji wspierającej przedsiębiorców branży garbarskiej [17]. Ze względu na znaczne nakłady inwestycyjne, istotne jest dokonanie analizy finansowej takiej inwestycji.

Wilgotne skóry w celu uniknięcia kurczenia się rozwieszane są na specjalnych drążkach (żerdziach) lub mocowane na drewnianych ramach w ogrzewanych komorach, zwanych suszarniami, gdzie poddawane są działaniu przepływającego gorącego powietrza. Podgrzany przez pompę ciepła strumień powietrza przepływając przez suszarnię oddaje swoje ciepło suszonym materiałom, przejmując od nich wilgoć. Najefektywniejszym sposobem jest suszenie skór powietrzem o temperaturze $30-50^{\circ} \mathrm{C}$ [11]. Cały proces odbywa się przez cały rok. Opisany sposób suszenia skór jest czasochłonny i wymaga, w zależności od rozmiaru zakładu, znacznej przestrzeni [14].

W omawianym $\mathrm{w}$ artykule przykładzie do suszenia skór przy użyciu pompy ciepła wykorzystano suszarnię tunelową. Jako źródło dolne może być wykorzystany grunt, woda, powietrze, ciepło odpadowe, itp. [20].

Analizę techniczno-finansową przeprowadzono dla następujących wariantów:

- Wariant I - pompa ciepła typu powietrze-woda,

- Wariant II - pompa ciepła typu solanka-woda współpracująca z poziomym gruntowym wymiennikiem ciepła,

- Wariant III - pompa ciepła typu solanka-woda współpracująca z pionowym wymiennikiem gruntowym,

- Wariant IV - pompa ciepła typu woda-woda pracująca w układzie bezpośrednim,

- Wariant V - pompa ciepła typu solanka-woda współpracująca ze ściekowym wymiennikiem ciepła. 


\subsection{Opis wariantu I}

$\mathrm{Na}$ opracowanym schemacie (rys. 1) przedstawiono instalację służącą do podgrzewania powietrza z użyciem pompy ciepła typu powietrze-powietrze w procesie suszenia skór. Powietrze atmosferyczne, mimo wielu wad jest obecnie bardzo popularnym źródłem ciepła niskotemperaturowego. Dzieje się tak między innymi dlatego, że jest źródłem energii odnawialnej charakteryzującym się łatwą dostępnością $\mathrm{w}$ dowolnych ilościach oraz stosunkowo niskimi kosztami inwestycyjnymi związanymi $\mathrm{z}$ jego ujęciem. Nie bez znaczenia pozostaje również fakt, że jego wykorzystanie nie powoduje żadnych zakłóceń równowagi cieplnej otoczenia [14].

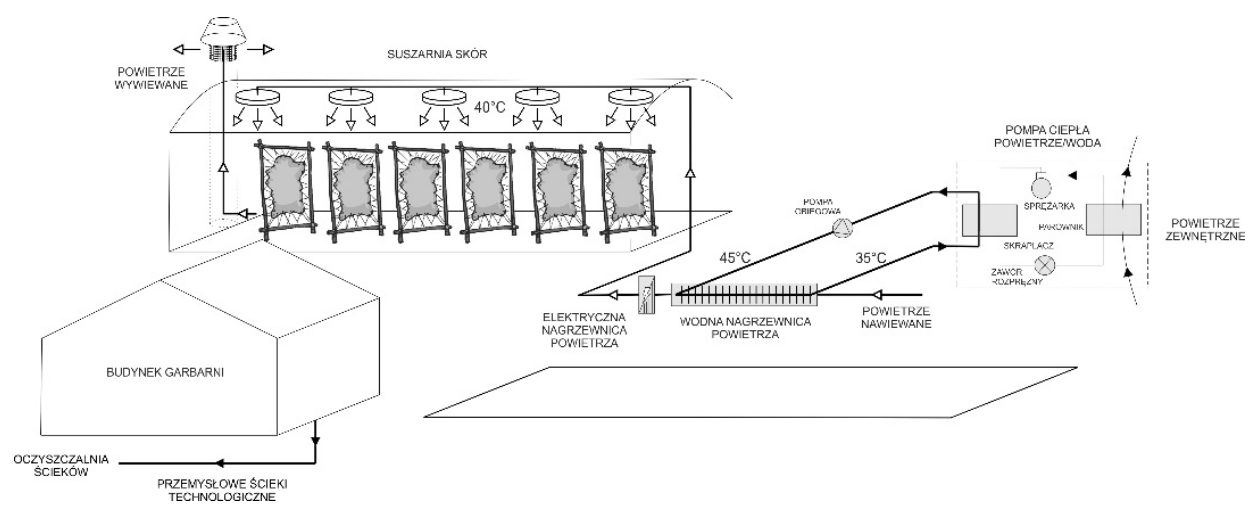

Rys. 1. Schemat systemu podgrzewania powietrza przy użyciu pompy ciepła typu powietrze-woda w procesie suszenia skór (wariant I)

Fig. 1. Diagram of air heating system with air-to-water heat pump in the drying process (variant I)

Powietrze atmosferyczne zasysane jest przez pompę ciepła, następnie schładzane w parowniku i ponownie odprowadzane do otoczenia. W przypadku występowania niskich temperatur zewnętrznych wymagane jest stosowanie okresowego odszraniania parownika, związane jest to jednak $\mathrm{z}$ dostarczaniem dodatkowej energii do tego celu. W takich przypadkach współczynniki wydajności grzewczej są bardzo niskie i strumień powietrza zewnętrznego kierowany do suszarni musi być dogrzewany do wymaganej temperatury przez elektryczną nagrzewnicę powietrza. W parowniku czynnik chłodniczy odbiera ciepło inicjując zmianę jego stanu skupienia $\mathrm{z}$ cieczy w gaz. Po przejściu przez parownik podnosi się także jego temperatura. W dalszej kolejności czynnik chłodniczy dochodzi do sprężarki, gdzie wzrastają jego ciśnienie i temperatura. Gorący czynnik chłodniczy skrapla się w skraplaczu i oddaje ciepło do wodnej instalacji grzewczej, czyli z powrotem zmienia swój stan skupienia z gazu na ciecz. Ostatnim etapem obiegu termodynamicznego jest rozprężenie w zaworze rozprężnym, gdzie ciśnienie zostaje zredukowane do poziomu wyjściowego, a czynnik chłod- 
niczy w stanie ciekłym dochodzi ponownie do parownika. Przyjęto, że powietrze nawiewane jest do budynku suszarni kanałem $\mathrm{z}$ wodną nagrzewnicą powietrza przy użyciu wentylatora nawiewnego. W nagrzewnicy zostaje ogrzane wodą, podłączoną do obiegu skraplacza pompy ciepła. Uzyskana temperatura powietrza nawiewanego do suszarni wynosi $40^{\circ} \mathrm{C}$. W obiekcie tym rozwieszony na specjalnych ramach materiał układany jest wzdłuż kanału, przez który transportowany jest czynnik suszący. Następnie zużyte powietrze wyrzucane jest kanałem powietrznym na zewnątrz przy użyciu wentylatora wywiewnego. Instalacja pomiędzy pompą ciepła a wymiennikami jest wykonana z rur z tworzyw sztucznych, kanały powietrzne zaś z blachy stalowej ocynkowanej. Przepływ czynnika grzewczego realizowany jest przy pomocy pomp obiegowych [14].

\subsection{Opis wariantu II}

Grunt jest odwiecznym akumulatorem energii cieplnej. Według aktualnego stanu wiedzy, w wierzchniej warstwie gruntu (ok. $10 \mathrm{~m}$ ), poniżej strefy przemarzania, zakumulowana jest energia cieplna pochodząca niemal wyłącznie od energii słonecznej i wymiany ciepła z atmosferą. Doświadczenia wykazały, że z jednego metra kwadratowego można oczekiwać wydajności poboru ciepła $q_{E}$ wynoszącej od 10 do $50 \mathrm{~W} / \mathrm{m}^{2}$, jako średniej wartości rocznej przy całorocznej eksploatacji $[4,14]$.

W opracowanym systemie podgrzewania powietrza dla tunelowej suszarni skór energia cieplna pobierana jest ze źródła dolnego - gruntu o temperaturze $10^{\circ} \mathrm{C}$, za pośrednictwem poziomego gruntowego wymiennika ciepła (rys. 2).

Nośnik ciepła krążący w wymienniku gruntowym pobiera zakumulowaną w gruncie energię cieplną i oddaje ją w parowniku ciekłemu czynnikowi chłodniczemu, w związku z czym następuje jego odparowanie przy stałym ciśnieniu. W dalszej kolejności chłodna para czynnika o niskim ciśnieniu przepływa do sprężarki, w której podnosi się jej temperatura i ciśnienie w wyniku procesu sprężania. W wymienniku tym gorąca para charakteryzująca się wysokim ciśnieniem oddaje ciepło wodzie krążącej między wodną nagrzewnicą powietrza a skraplaczem. W związku z tym do nagrzewnicy trafia woda o wysokiej temperaturze, która podgrzewa powietrze płynące $\mathrm{z}$ zewnątrz, kierowane następnie do suszarni skór. Opuszczający skraplacz przechłodzony ciekły czynnik o wysokim ciśnieniu kierowany jest do zaworu rozprężnego, w którym następuje obniżenie jego ciśnienia i temperatury w wyniku dławienia izentalpowego, jak również zmienia się jego stan skupienia. Ochłodzona mieszanina dwufazowa pary oraz ciekłego czynnika chłodniczego przepływa następnie do parownika, a cały cykl się powtarza [14]. 


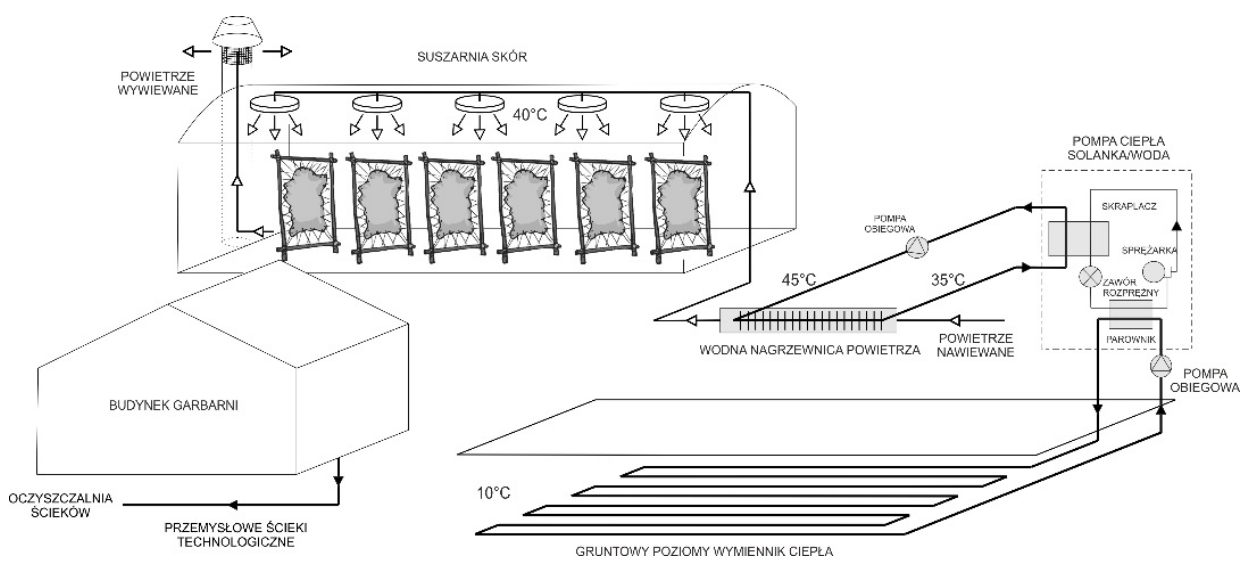

Rys. 2. Schemat systemu podgrzewania powietrza przy użyciu pompy ciepła typu solanka-woda współpracującej $\mathrm{z}$ gruntowym poziomym wymiennikiem ciepła $\mathrm{w}$ procesie suszenia skór (wariant II)

Fig. 2. Diagram of air heating system using brine-to-water heat pump in cooperation with horizontal ground heat exchanger in the drying process (variant II)

\subsection{Opis wariantu III}

Zaproponowany wariant podgrzewania powietrza w procesie suszenia skór z użyciem pompy ciepła różni się rozwiązaniem obiegu dolnego. Ciepło również jest pobierane ze źródła niskotemperaturowego, jakim jest grunt o temperaturze $10^{\circ} \mathrm{C}$, ale za pośrednictwem pionowego gruntowego wymiennika ciepła. $\mathrm{W}$ tego typu wymiennikach orientacyjne strumienie energii cieplnej możliwe do osiągnięcia $\mathrm{z}$ jednego metra długości wynoszą ok. 25-70 W. Zakumulowana w głębszych warstwach ziemi (poniżej $20 \mathrm{~m}$ ) energia cieplna pochodzi nie tylko od promieniowania słonecznego, ale również od wnętrza ziemi. Zarówno wewnętrzny obieg termodynamiczny, jak również obieg górnego źródła ciepła przebiega w analogiczny sposób jak w wariancie poprzednim.

Rysunek 3 przedstawia schemat opisanej instalacji suszenia skór przy pomocy pompy ciepła współpracującej z pionowym wymiennikiem gruntowym.

\subsection{Opis wariantu IV}

Zilustrowany na rysunku 4 system zaopatrzenia w ciepło wodnej nagrzewnicy powietrza przy pomocy pompy ciepła w procesie suszenia skór wykorzystuje jako dolne źródło ciepła wodę powierzchniową. Medium to stanowi szczególnie korzystne źródło niskotemperaturowe, z uwagi na jego dużą pojemność cieplną $[5,14]$. Woda powierzchniowa z powodzeniem może transportować znaczną ilość energii cieplnej, nie powodując przy tym zachwiania równowagi termicznej środowiska. 
Woda ze zbiornika jest tłoczona przy użyciu pompy głębinowej do parownika pompy ciepła. Następnie po przejściu przez parownik medium wtłaczane jest ponownie do zbiornika. W wymienniku tym czynnik chłodniczy odbiera energię cieplną od wody. Gorący czynnik chłodniczy ulega skropleniu w skraplaczu pompy ciepła i oddaje ciepło wodzie zasilającej wodną nagrzewnicę powietrza.

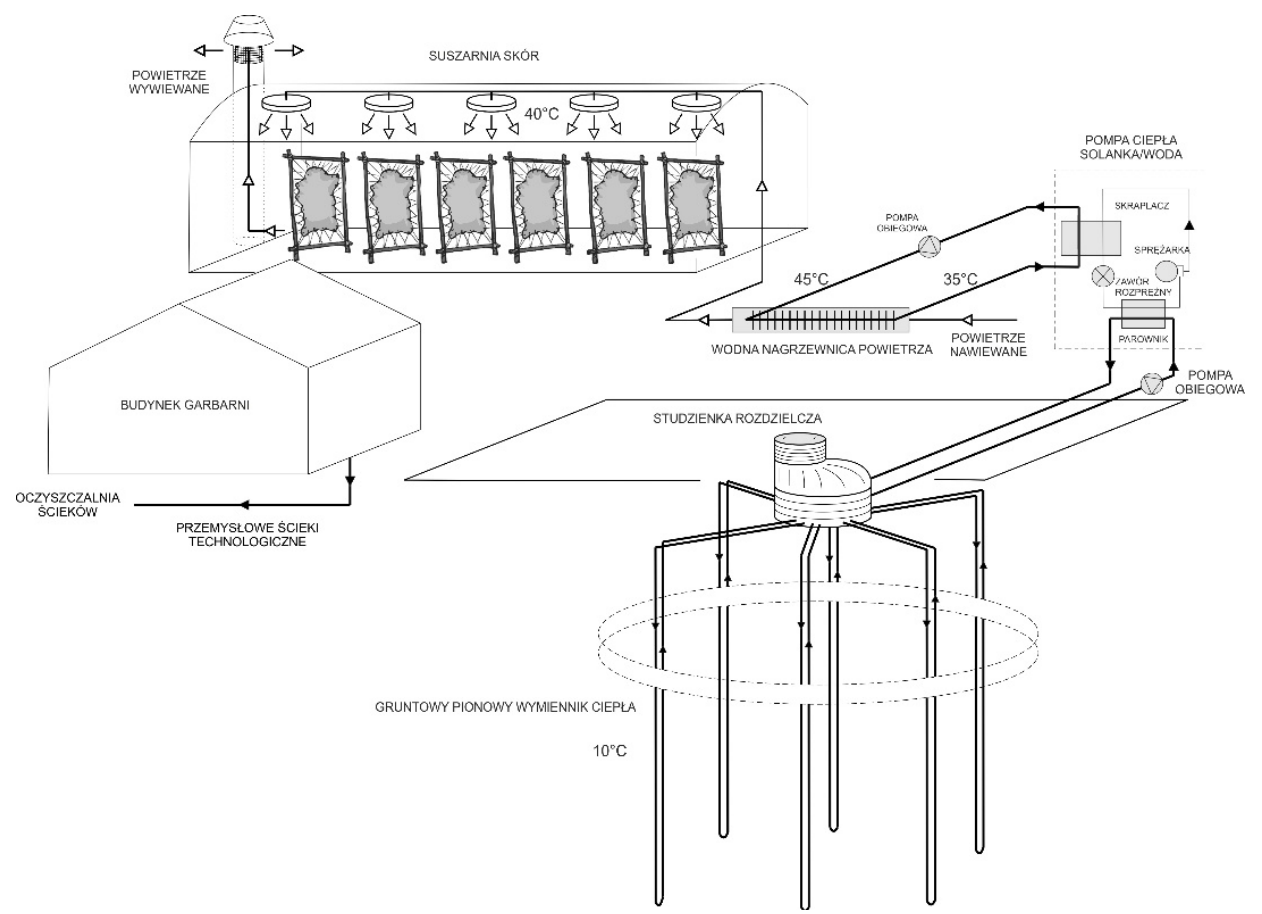

Rys. 3. Schemat systemu podgrzewania powietrza przy użyciu pompy ciepła typu solanka-woda współpracującej $\mathrm{z}$ gruntowym pionowym wymiennikiem ciepła $\mathrm{w}$ procesie suszenia skór (wariant III)

Fig. 3. Diagram of air heating system using brine-to-water heat pump in cooperation with vertical ground heat exchanger in the drying process (variant III)

W skład instalacji dolnego źródła ciepła wchodzi pompa głębinowa tłocząca wodę do parownika, zawory odcinające usytuowane na zasilaniu i powrocie instalacji oraz filtr zapobiegający przed dostawaniem się zanieczyszczeń, który umieszczony jest na zasilaniu.

Głównymi elementami składowymi instalacji grzewczej są: pompa obiegowa wymuszająca przepływ czynnika grzewczego, zawór zwrotny chroniący pompę przed niekorzystną zmianą kierunku przepływu wody, zawory odcinające usytuowane na zasilaniu i powrocie instalacji, filtr eliminujący zanieczyszczenia, naczynie wzbiorcze oraz zawór bezpieczeństwa chroniące instalację przed 
nadmiernym wzrostem ciśnienia, jak również wodna nagrzewnica powietrza [14].

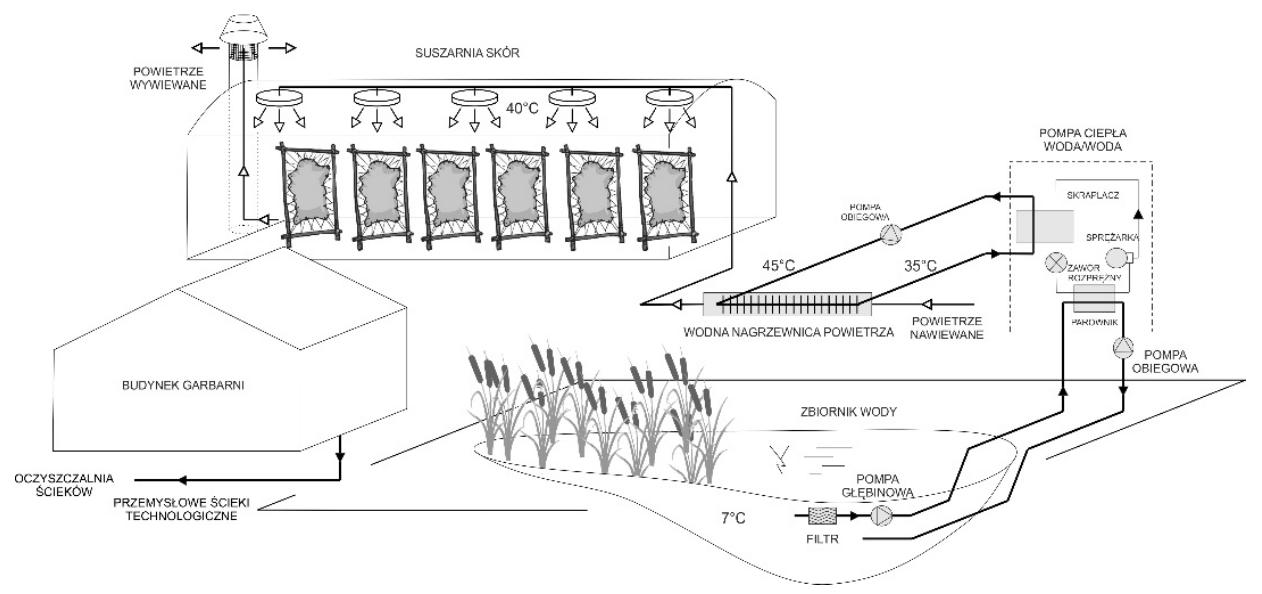

Rys. 4. Schemat systemu podgrzewania powietrza przy użyciu pompy ciepła typu woda-woda w procesie suszenia skór (wariant IV)

Fig. 4. Diagram of air heating system with water-to-water heat pump in the drying process (variant IV)

\subsection{Opis wariantu V}

Proces garbowania wymaga zastosowania m.in. kąpieli wodnych skór, które należą do niezwykle wodochłonnych etapów technologicznych, a zużycie wody niezbędnej do produkcji skór zależy generalnie od wielkości zakładu oraz wykorzystywanej technologii. Ilość wody zużywana przeciętnie w krajowych garbarniach wynosi około $20-65 \mathrm{~m}^{3}$ na 1 tonę skór surowych $[8,12,16]$. W związku z powyższym wiąże się to z powstawaniem bardzo dużej ilości ścieków powstałych w procesach: moczenia, wapnienia, odwapniania, garbowania oraz wykańczania [24]. Często dodatkowym źródłem ścieków okazuje się wykorzystanie pozaprocesowe, tj. mycie i chłodzenie maszyn oraz różne prace porządkowe [17]. Jednym $\mathrm{z}$ awangardowych zastosowań jest wykorzystanie energetyczne przemysłowych ścieków technologicznych po procesie garbowania skór, jako sztucznego źródła ciepła.

Zakłady garbarskie są zaopatrzone w duże gabarytowo zbiorniki na ścieki przemysłowe. Dzięki temu możliwe jest uniknięcie znacznych kosztów inwestycyjnych na ich budowę myśląc o wykorzystaniu energetycznym tego źródła odpadowego [25].

Temperatura przemysłowych ścieków technologicznych jest wyższa od temperatury źródeł odnawialnych, a ich dostępność zgodna z czasem i wielkością zapotrzebowania na energię. Stwarza to dogodne warunki do wykorzystania 
ich w pompach ciepła. Przykładowo, według informacji uzyskanych od specjalistów, temperatura usuwanych ścieków technologicznych powstałych w procesie garbowania skór wynosi około $18^{\circ} \mathrm{C}$.

$\mathrm{Na}$ rysunku 5 przedstawiono schemat instalacji podgrzewania powietrza przy użyciu pompy ciepła współpracującej z wymiennikiem ściekowym w procesie suszenia skór.

Instalacja pobiera ciepło odpadowe $\mathrm{z}$ przemysłowych ścieków technologicznych za pomocą ściekowego wymiennika ciepła, który usytuowany został w zamkniętym zbiorniku pod powierzchnią terenu. Do przekazania energii cieplnej ze ścieków do parownika służy niskokrzepnąca ciecz, roztwór na bazie glikolu etylenowego. Obieg nośnika ciepła wymuszony jest działaniem pompy obiegowej.

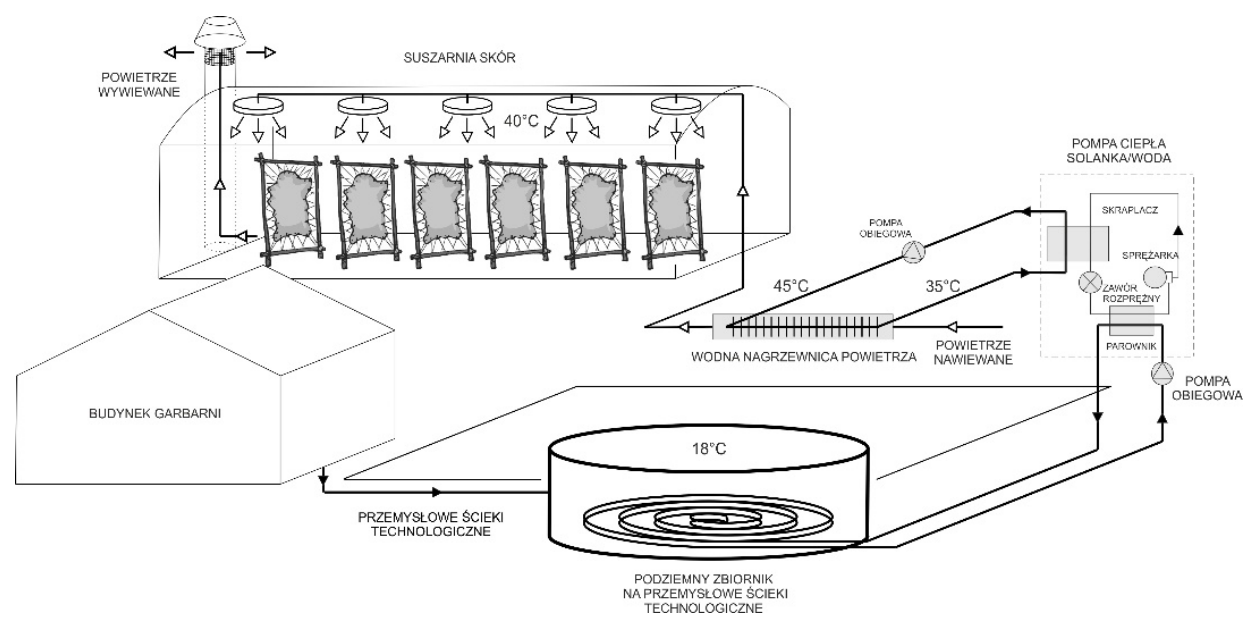

Rys. 5. Schemat systemu podgrzewania powietrza przy użyciu pompy ciepła typu solanka-woda współpracującej z wymiennikiem ściekowym w procesie suszenia skór (wariant V)

Fig. 5. Diagram of air heating system using brine-to-water heat pump in cooperation with a wastewater heat exchanger in the drying process (variant $\mathrm{V}$ )

\section{Zastosowanie wykresów i-x powietrza wilgotnego do określenia parametrów technologicznych suszarni skór}

Przebieg zmian stanu powietrza na wykresie $\mathrm{i}-\mathrm{x}$ powietrza wilgotnego w procesie suszenia z pracującą pompą ciepła w okresie zimowym (rys. 6) rozpoczęto od naniesienia parametrów powietrza zewnętrznego (punkt 1). Z punktu 1 poprowadzono prostą po linii $x=$ const. do przecięcia się z linią temperatury $40^{\circ} \mathrm{C}$ (punkt 2), czyli założoną początkową temperaturą strumienia powietrza przed suszarnią tunelową. Punkt ten charakteryzuje parametry technologiczne powietrza ogrzanego przy pomocy pomy ciepła oraz wodnej nagrzewnicy po- 
wietrza. W dalszej kolejności, podczas przeprowadzania procesu suszenia skór, z punktu 2 wzdłuż stałej linii $i=$ const. (proces teoretyczny suszenia) przeprowadzono prostą, do przecięcia się z linią $\varphi=70 \%$ (według danych z praktyki eksploatacji suszarni konwekcyjnych). W ten sposób otrzymano parametry powietrza po procesie suszenia (punkt 3). Etap 1-2 charakteryzuje proces ogrzania strumienia powietrza przy użyciu pompy ciepła, z kolei etap 2-3 przedstawia zmiany stanu powietrza w suszarni w procesie suszenia skór [14].

$\mathrm{W}$ okresie letnim (miesiąc czerwiec) przebieg zmian stanu powietrza na wykresie i-x powietrza wilgotnego w procesie suszenia skór z pracującą pompą ciepła jest analogiczny (rys. 7). Obraz przemiany powietrza rozpoczęto opracowywać od naniesienia parametrów powietrza zewnętrznego (punkt 1). Z punktu 1, przyjmując stałą zawartość wilgoci $x=$ const. (ogrzewanie strumienia powietrza do suszenia skór przy użyciu pompy ciepła), poprowadzono prostą aż do przecięcia się z linią temperatury $40^{\circ} \mathrm{C}$ (punkt 2). W dalszej kolejności, z punktu 2 , przy stałej entalpii właściwej $i=$ const. (proces teoretyczny suszenia) wyznaczono prostą. W miejscu jej skrzyżowania się z linią $\varphi=70 \%$ otrzymano parametry powietrza po procesie suszenia (punkt 3), a odcinek 2-3 charakteryzuje zmiany stanu powietrza w procesie suszenia skór [14].

\section{Obliczenie wariantów systemu}

Na podstawie przyjętych założeń dokonano obliczenia poszczególnych wariantów. W obliczeniach bazowano na danych wyjściowych, którymi są:

- temperatura suszenia skór: $t_{N}=40^{\circ} \mathrm{C}[11]$,

- parametry suszonego materiału: masa początkowa $G_{p}=600 \mathrm{~kg}$, wilgotność początkowa $w_{p}=65 \%$ [14], wilgotność końcowa $w_{k}=5 \%$ [14],

- parametry obliczeniowe powietrza zewnętrznego:

okres zimowy, III strefa klimatyczna, miesiąc grudzień [15]:

temperatura termometru suchego $t_{Z}=-20^{\circ} \mathrm{C}$, zawartość wilgoci $x_{Z}=0,8 \mathrm{~g} / \mathrm{kg}$, wilgotność względna $\varphi_{Z}=100 \%$, entalpia właściwa $i_{Z}=-18,4 \mathrm{~kJ} / \mathrm{kg}$,

okres letni, II strefa klimatyczna, miesiąc czerwiec [15]:

temperatura termometru suchego $t_{Z}=28,2^{\circ} \mathrm{C}$, zawartość wilgoci $x_{Z}=12,4 \mathrm{~g} / \mathrm{kg}$, wilgotność względna $\varphi_{Z}=52 \%$, entalpia właściwa $i_{Z}=60,8 \mathrm{~kJ} / \mathrm{kg}$,

- dolne źródło ciepła: powietrze atmosferyczne dla okresu zimowego $T_{p z}=-11^{\circ} \mathrm{C}$ [7] (dolna granica zakresu pracy dolnego źródła ciepła pompy ciepła w trybie grzania) i dla okresu letniego $T_{p l}=28,2^{\circ} \mathrm{C}$ [15] (wariant I), grunt o temperaturze $T_{\mathrm{g}}=10^{\circ} \mathrm{C}[14,19]$ (wariant II i III), woda powierzchniowa o temperaturze $T_{\mathrm{w}}=7^{\circ} \mathrm{C}$ [14] (wariant IV), przemysłowe ścieki technologiczne o temperaturze $T_{\dot{s} \dot{c}}=18^{\circ} \mathrm{C}($ wariant $\mathrm{V})$, 
- wymienniki gruntowe usytuowane są w wilgotnym gruncie piaszczystym o jednostkowym poborze ciepła $\mathrm{z}$ gruntu: poziomy $q_{E}=20 \mathrm{~W} / \mathrm{m}[14,19,21]$ (wariant II), pionowy $q_{E}=40 \mathrm{~W} / \mathrm{m}[14,19,21]$ (wariant III),

- temperatura zasilania wodnej nagrzewnicy powietrza: $t_{Z N}=45^{\circ} \mathrm{C}$.

Ilość usuwanej wilgoci $W$ obliczono ze wzoru (1), przy założeniu, że proces suszenia będzie odbywał się $\mathrm{w}$ przeciągu doby [13].

$$
W=G_{p} \cdot \frac{w_{p}-w_{k}}{100-w_{k}}
$$

gdzie: $G_{p}$ - masa początkowa wilgotnego materiału, $\mathrm{kg}$;

$w_{p}$ - początkowa wilgotność materiału, \%;

$w_{\mathrm{k}}$ - końcowa wilgotność materiału, $\%$.

Właściwe zużycie powietrza suchego $l$ obliczono w oparciu o wzór (2) [13].

$$
l=\frac{1}{x_{w}-x_{z}}
$$

gdzie: $x_{\mathrm{w}}$ - zawartość wilgoci w powietrzu po procesie suszenia, g/kg;

$x_{\mathrm{z}}$-zawartość wilgoci w powietrzu przed procesem suszenia, $\mathrm{g} / \mathrm{kg}$.

Ze wzoru (3) obliczono natężenie przepływu powietrza $L$ [13].

$$
L=l \cdot W
$$

gdzie: $l$ - właściwe zużycie powietrza suchego, $\mathrm{kg} / \mathrm{kg}$;

$W$-ilość usuwanej wilgoci, $\mathrm{kg} / \mathrm{h}$.

Właściwe zużycie ciepła $q$ obliczono według zależności (4) [13].

$$
q=\frac{i_{w}-i_{z}}{x_{w}-x_{z}}
$$

gdzie: $i_{\mathrm{w}}$ - entalpia właściwa powietrza po procesie suszenia, $\mathrm{kJ} / \mathrm{kg}$;

$i_{\mathrm{z}}$ - entalpia właściwa powietrza przed procesem suszenia, $\mathrm{kJ} / \mathrm{kg}$.

Natężenie przepływu ciepła obliczono z poniższej zależności (5) [13].

$$
Q=W \cdot q
$$

gdzie: $W$ - ilość usuwanej wilgoci, $\mathrm{kg} / \mathrm{h}$;

$q$ - właściwe zużycie ciepła, $\mathrm{kJ} / \mathrm{kg}$ odp. wilgoci. 


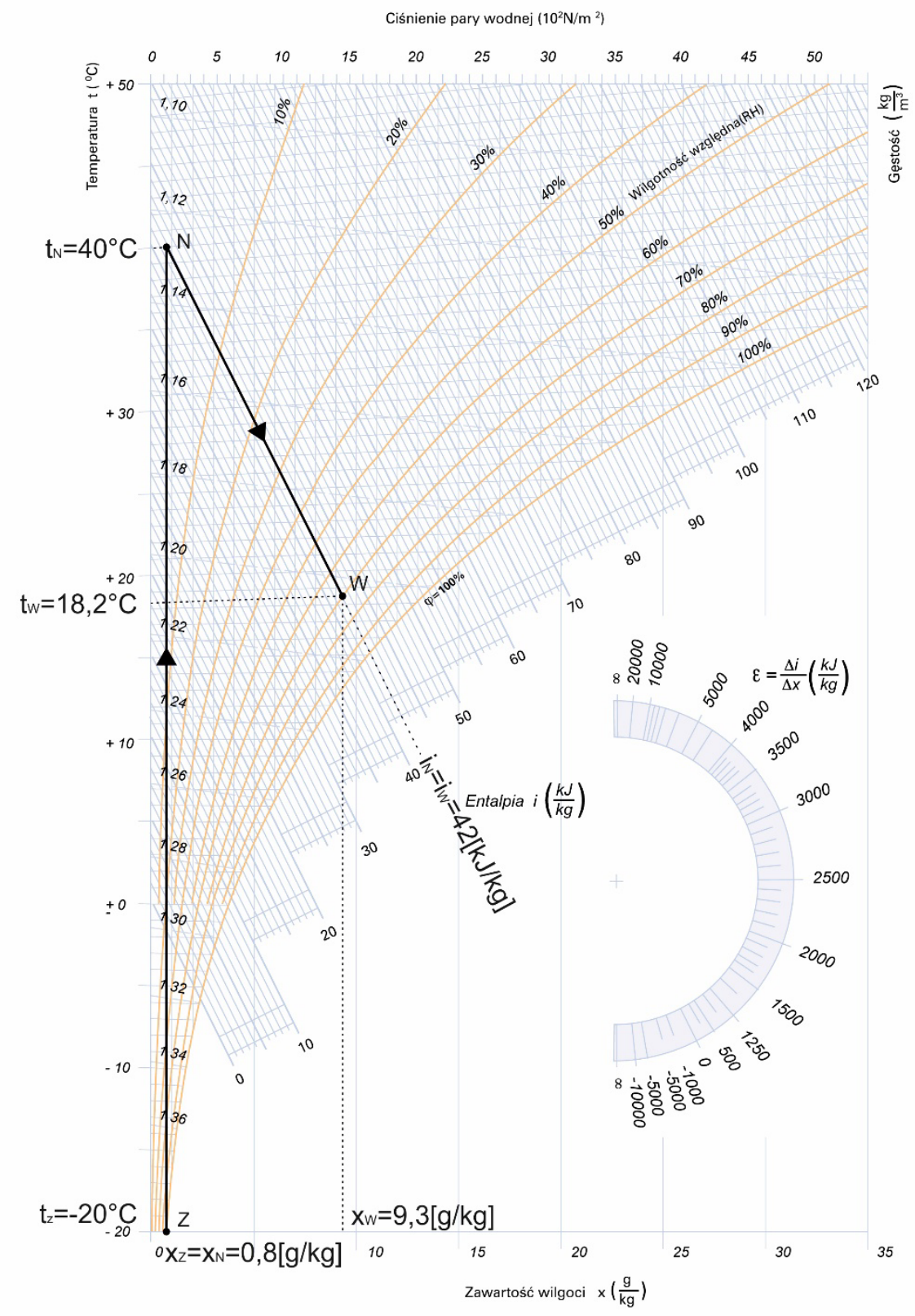

Rys. 6. Proces suszenia skór na wykresie i-x powietrza wilgotnego w okresie zimowym (na podstawie [14])

Fig. 6. Leather drying process in the winter, shown on the $\mathrm{i}-\mathrm{x}$ chart for humid air (based on [14]) 


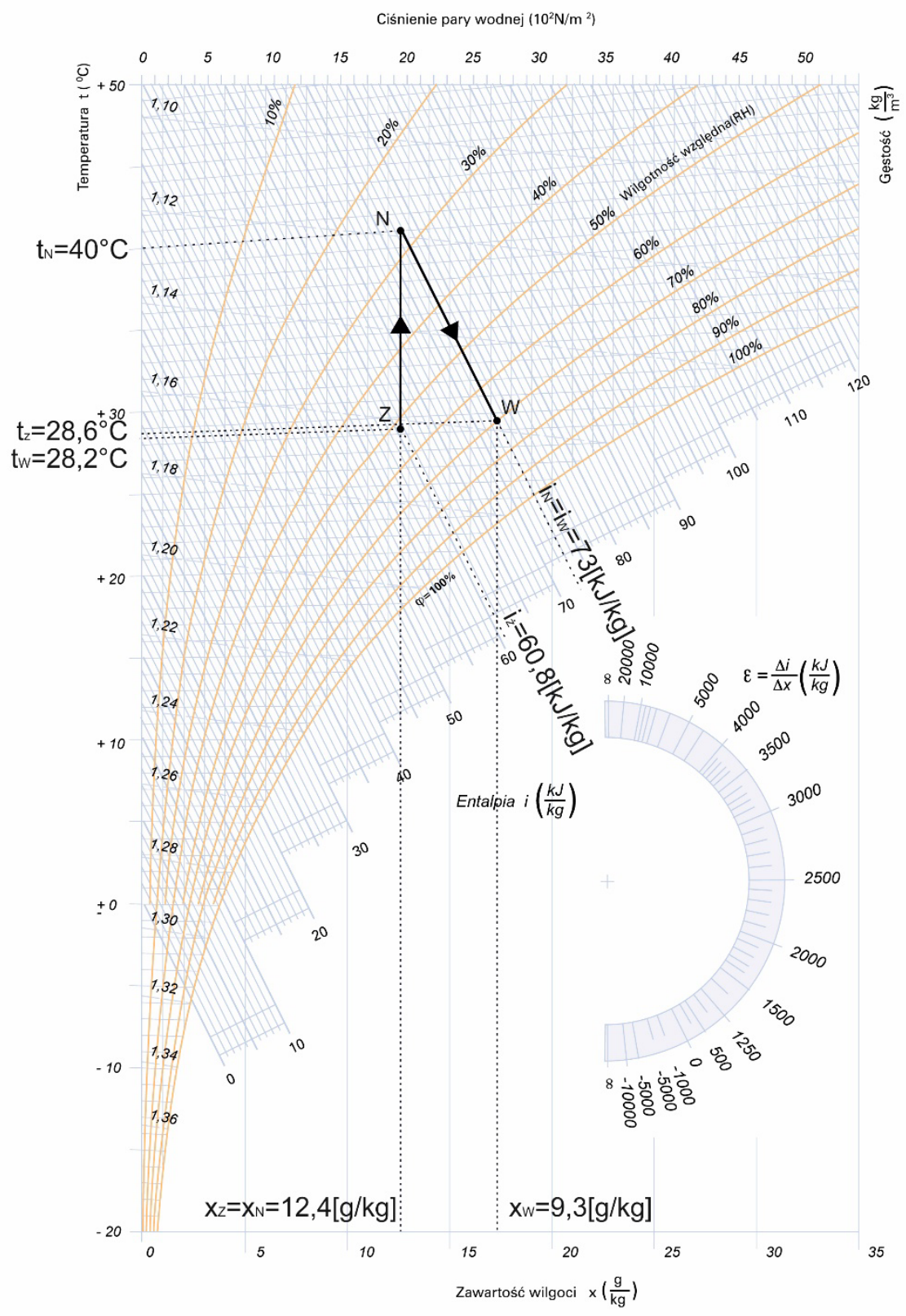

Rys. 7. Proces suszenia skór na wykresie i-x powietrza wilgotnego w okresie letnim (na podstawie [14])

Fig. 7. Leather drying process in the summer, shown on the i-x chart for humid air (based on [14]) 
Wyniki przeprowadzonych obliczeń przedstawiono w tabeli 1.

Tabela 1. Zestawienie wyników obliczeń parametrów technologicznych suszarni skór dla okresu letniego i zimowego

Table 1. Summary of the results of calculations of technological parameters of drying leather for the summer and winter period

\begin{tabular}{|c|c|c|}
\hline \multicolumn{3}{|c|}{ Zestawienie wyników obliczeń parametrów technologicznych suszarni skór } \\
\hline Okres & letni & zimowy \\
\hline $\begin{array}{c}\text { Ciężar początkowy wilgotnego } \\
\text { materiału } G_{\mathrm{p}}, \mathrm{kg}\end{array}$ & \multicolumn{2}{|c|}{600} \\
\hline Ilość usuwanej wilgoci $W, \mathrm{~kg} / \mathrm{h}$ & \multicolumn{2}{|c|}{15,8} \\
\hline $\begin{array}{c}\text { Właściwe zużycie powietrza } \\
\text { suchego } l, \mathrm{~kg} / \mathrm{kg} \text { odp. wilgoci }\end{array}$ & 192,31 & 117,65 \\
\hline $\begin{array}{c}\text { Natężenie przepływu powietrza } L, \\
\mathrm{~kg} / \mathrm{h}\end{array}$ & 3036,44 & 1857,59 \\
\hline $\begin{array}{c}\text { Właściwe zużycie ciepła } q, \\
\mathrm{~kJ} / \mathrm{kg} \text { odp. wilgoci }\end{array}$ & 2346,15 & 7105,88 \\
\hline Natężenie przepływu ciepła $Q, \mathrm{~kJ} / \mathrm{h}$ & 37044,53 & 112198,14 \\
\hline $\begin{array}{c}\text { Obliczona moc układu } \\
\text { do przygotowania ciepłej wody } \\
\text { technologicznej } Q_{\mathrm{z}}, \mathrm{kW}\end{array}$ & 10,29 & 31,17 \\
\hline
\end{tabular}

$\mathrm{Na}$ podstawie sporządzonych obliczeń oraz danych technicznych dostępnych w katalogach producentów dobrano przykładowe pompy ciepła dostępne na rynku [7] (tabela 2).

Ilość ciepła $Q_{d}$, którą należy pozyskać ze źródła niskotemperaturowego, obliczono ze wzoru (6) [14].

$$
Q_{d}=Q \cdot \frac{\varphi-1}{\varphi}
$$

gdzie: $Q$ - moc grzejna pompy ciepła (moc oddawana na skraplaczu), kW;

$\varphi-$ znamionowy współczynnik wydajności grzejnej pompy ciepła COP odczytany z karty katalogowej producenta [7], -.

Korzystając ze wzoru (7) oraz z wielkości podanych w tabeli 1, obliczono wymaganą długość wymiennika $L$ konieczną do odebrania ciepła ze źródła niskotemperaturowego [14].

$$
L_{w}=\frac{Q_{d}}{q_{E}}
$$


gdzie: $Q_{d}-$ moc cieplna pozyskana ze źródła niskotemperaturowego, $\mathrm{kW}$;

$q_{E}$ - jednostkowa moc cieplna pobierana ze źródła niskotemperaturowego, $\mathrm{W} / \mathrm{m}$.

Ściekowy wymiennik ciepła (wariant V) zaprojektowano w postaci klatek energetycznych GEO CALIX firmy UPONOR [23] usytuowanych w podziemnym zamkniętym zbiorniku na przemysłowe ścieki technologiczne powstające na terenie zakładu garbarskiego. Jednostkowy odbiór ciepła ze ścieków $q_{\mathrm{e}}$ założono na bezpiecznym poziomie $40 \mathrm{~W} / \mathrm{m}$.

Wyniki powyższych obliczeń przedstawiono w tabeli 2.

Tabela 2. Porównanie technologiczne instalacji podgrzewania powietrza przy użyciu pompy ciepła w procesie suszenia skór

Table 2. Technological comparison of air heating system installations using heat pump in the drying process

\begin{tabular}{|c|c|c|c|c|c|c|}
\hline \multicolumn{7}{|c|}{ Porównanie technologiczne instalacji dla tunelowej suszarni skór } \\
\hline \multirow{2}{*}{$\begin{array}{l}\text { Wariant oblicze- } \\
\text { niowy }\end{array}$} & \multicolumn{2}{|c|}{ I } & \multirow{2}{*}{ II } & \multirow{2}{*}{ III } & \multirow{2}{*}{ IV } & \multirow{2}{*}{$\mathrm{V}$} \\
\hline & zima & lato & & & & \\
\hline Typ pompy ciepła & \multicolumn{2}{|c|}{$\begin{array}{c}\text { Dimplex } \\
\text { typ } \\
\text { LA 60TUR+ }\end{array}$} & \multicolumn{2}{|c|}{$\begin{array}{l}\text { Dimplex } \\
\text { typ } \\
\text { SI 26TU }\end{array}$} & 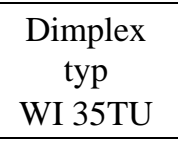 & $\begin{array}{l}\text { Dimplex } \\
\text { typ } \\
\text { SI 22TU }\end{array}$ \\
\hline Źródło ciepła & \multicolumn{2}{|c|}{$\begin{array}{l}\text { powietrze } \\
\text { zewnętrzne }\end{array}$} & \multicolumn{2}{|c|}{ grunt } & $\begin{array}{l}\text { Woda } \\
\text { powierzch- } \\
\text { wierzch- } \\
\text { niowa }\end{array}$ & $\begin{array}{l}\text { ścieki } \\
\text { technolo- } \\
\text { giczne }\end{array}$ \\
\hline $\begin{array}{c}\text { Moc grzewcza } \\
\text { pompy ciepła } Q_{p c}, \\
\text { kW }\end{array}$ & 35 & 49 & \multicolumn{2}{|c|}{32} & 32 & 32 \\
\hline $\begin{array}{c}\text { Moc chłodnicza } \\
\text { pompy ciepła } \\
Q_{c h}, \mathrm{~kW}\end{array}$ & 20 & 38,8 & \multicolumn{2}{|c|}{25,2} & 25 & 25,5 \\
\hline $\begin{array}{c}\text { Pobór mocy } \\
\text { elektrycznej } P, \mathrm{~kW}\end{array}$ & 15 & 10,2 & \multicolumn{2}{|c|}{6,8} & 7 & 6,5 \\
\hline $\begin{array}{c}\text { Stopień } \\
\text { efektywności } \varphi,-\end{array}$ & 2,34 & 4,8 & \multicolumn{2}{|c|}{4,7} & 4,6 & 4,9 \\
\hline Czynnik chłodniczy & \multicolumn{2}{|c|}{ R417A } & \multicolumn{2}{|c|}{ R410A } & R410A & R407C \\
\hline $\begin{array}{l}\text { Obliczona ilość } \\
\text { ciepła jaką należy } \\
\text { pobrać ze źródła } \\
\text { niskotemperaturo- } \\
\text { wego } Q_{d}, \mathrm{~kW}\end{array}$ & \multicolumn{2}{|c|}{17,8} & \multicolumn{2}{|c|}{24,5} & 24,4 & 24,8 \\
\hline $\begin{array}{c}\text { Wymagana długość } \\
\text { wymiennika } L, \mathrm{~m}\end{array}$ & \multicolumn{2}{|c|}{-} & 1260 & 630 & - & 637 \\
\hline
\end{tabular}


Analizując dane z tabeli 2 można zauważyć, że najwyższym współczynnikiem wydajności (COP) charakteryzuje się pompa ciepła typu solanka-woda, wykorzystująca jako źródło ciepła niskotemperaturowego ścieki technologiczne, zastosowana w wariancie V. W wariancie II obliczona wymagana długość wymiennika jest największa, z uwagi na niższy jednostkowy pobór ciepła z gruntu $q_{E}$ charakterystyczny dla poziomych wymienników gruntowych.

W pompach ciepła do rzadkości należy tzw. modulacja mocy, czyli dopasowanie do bieżących potrzeb, zatem przez znaczny okres czasu pracują z nadmiarem mocy, wykorzystywanym tylko w okresie zimowym. Zatem w naszym obecnym klimacie wybierając pompę ciepła o mocy wystarczającej do podgrzania powietrza $\mathrm{w}$ procesie suszenia przy $-11^{\circ} \mathrm{C}$ na zewnątrz, wykorzystującą jako dolne źródło ciepła powietrze atmosferyczne, decydujemy się na urządzenie $\mathrm{z}$ dużym zapasem mocy dla temperatur panujących w okresie letnim. Ponoszone są w takiej sytuacji wyższe koszty za urządzenie o większej (za dużej) mocy i pompa ciepła pracuje przez okres letni ze znacznym nadmiarem mocy, a więc w warunkach dalekich od optymalnych.

W związku z powyższym, należałoby rozpatrzyć rozwiązanie, w którym jako dolne źródło ciepła wykorzystywane jest nie powietrze zewnętrzne, a powietrze usuwane z budynku suszarni tunelowej charakteryzujące się znacznie wyższymi temperaturami w okresie zimowym, opisane w literaturze [14].

\section{Ocena efektywności finansowej inwestycji}

Instalacje z pompami ciepła oraz inne źródła niekonwencjonalne to systemy, w przypadku których horyzont czasowy pozwalający na zaobserwowanie korzyści ekonomicznych jest stosunkowo długi. W wyniku tego uzasadnione jest zastosowanie w obliczeniach metod dyskontowych [3].

Wykonując ocenę efektywności finansowej zastosowania omówionych wariantów podgrzewania powietrza $\mathrm{w}$ procesie suszenia skór $\mathrm{w}$ zakładzie garbarskim przeprowadzono analizę finansową według metody kosztów rocznych opisanej w [9]. Istotą tej metody jest umożliwienie obliczenia kosztów wytwarzania ciepła, w skład których wchodzą koszty bieżące (eksploatacyjne), jak również koszty wywodzące się od zwrotu nakładów inwestycyjnych naliczane w przedziale czasowym jednego roku. Jest on rokiem reprezentatywnym dla analizowanego horyzontu czasowego ekonomicznej eksploatacji obiektu - liczącego $N$ lat [9].

W całkowitych nakładach inwestycyjnych znaczny udział przypada pompie ciepła oraz wymiennikowi niskotemperaturowemu. Szacując wysokość nakładów inwestycyjnych na poszczególne składniki instalacji grzewczej z pompą ciepła oparto się na informacjach uzyskanych od producentów pomp ciepła oraz w literaturze [9].

Tabela 3 przedstawia wyniki obliczeń kosztów poszczególnych elementów układu wchodzących w skład całkowitych kosztów inwestycyjnych. Założono, 
że koszt pozostałych elementów instalacji wynosi $20 \%$ (wariant I, II, IV i V) oraz 16\% (wariant III) zgodnie z propozycją [9].

Tabela 3. Nakład inwestycyjny instalacji dla poszczególnych wariantów

Table 3. Cost of the installation for the individual variants

\begin{tabular}{|c|c|c|c|c|c|}
\hline \multicolumn{6}{|c|}{ Nakłady inwestycyjne dla poszczególnych wariantów } \\
\hline Wariant & I & II & III & IV & V \\
\hline Pompa ciepła, zł & 139900,0 & \multicolumn{2}{|c|}{48300,0} & 44900,0 & 31700,0 \\
\hline Wymiennik ciepła, zł & - & 62100,0 & 91603,4 & 26940,0 & 40757,1 \\
\hline $\begin{array}{l}\text { Pozostałe elementy instala- } \\
\text { cji: wodna nagrzewnica } \\
\text { powietrza, rurociagi, } \\
\text { armatura, układ automatyki } \\
\text { oraz robocizna } \\
\text { i uruchomienie instalacji, zł }\end{array}$ & 34975,0 & 27600,0 & 26648,3 & 17960,0 & 18114,3 \\
\hline $\begin{array}{c}\text { Sumaryczny nakład } \\
\text { inwestycyjny }\left(K_{\text {inpc }}\right) \text {, zł }\end{array}$ & 174875,0 & 138000,0 & 166551,7 & 89800,0 & 90571,4 \\
\hline
\end{tabular}

Analizując dane z tabeli 3 można zauważyć, że najwyższe koszty inwestycyjne uzyskał wariant I z pompą ciepła typu powietrze-woda. Z kolei najniższe koszty inwestycyjne wymagane są na realizację wariantu IV, w którym pompa ciepła wykorzystuje jako źródło ciepła niskotemperaturowego wodę powierzchniową. Układ ten pracuje w systemie bezpośrednim, stąd koszt wykonania ujęcia jest niższy w porównaniu do wymienników gruntowych. Dla rozpatrywanej suszarni tunelowej koszt wykonania pionowego gruntowego wymiennika ciepła byłby około $32 \%$ wyższy w odniesieniu do poziomego, pomijając koszt zakupu gruntu pod jego powierzchnię.

Założony czas eksploatacji opisanego systemu, który odpowiada czasowi bezawaryjnej pracy sprężarek pomp ciepła, przyjęto na poziomie $N=15$ lat, zgodnie $\mathrm{z}$ zaleceniami producentów (wymiana informacji $\mathrm{w}$ rozmowach z przedstawicielami różnych przedsiębiorstw). Średnią cenę energii elektrycznej założono zgodnie $\mathrm{z}$ informacją Prezesa Regulacji Energetyki równą $c_{e l}=0,606 \mathrm{zt} / \mathrm{kWh}[10]$. Natomiast obliczenia wartości zaktualizowanej netto przedsięwzięcia przeprowadzono dla wartości stopy dyskontowej $\mathrm{p}=6 \%$ zalecanej dla obiektów energetyki odnawialnej [9].

Ratę zwrotu kapitałowego (rozszerzonej reprodukcji) $r$ obliczono z zależności (8) [9].

$$
r=\frac{p \cdot(1+p)^{N}}{(1+p)^{N}-1}
$$

gdzie: $p$ - stopa dyskontowa, \%; 
$N$ - obliczeniowy okres eksploatacji systemu, lata.

Ratę kosztów stałych $r+r_{c e}$, czyli sumę raty rozszerzonej reprodukcji i raty kosztów eksploatacyjnych stałych, obliczono ze wzoru (9) [9].

$$
r+r_{c e}=0,12
$$

gdzie: $r_{c e}$ - stopa stałych kosztów eksploatacyjnych, \%; przyjęto $2 \%$ na podstawie propozycji [9].

W celu obliczenia rocznych kosztów stałych $K_{r s t}$ wykorzystano wzór (10) [9].

$$
K_{r s t}=K_{r r}+K_{e s t}=K_{i n p c} \cdot r+K_{i n p c} \cdot r_{c e}=\left(r+r_{c e}\right) \cdot K_{i n p c}
$$

gdzie: $K_{r r}$ - suma kosztów zwrotu kapitałowego, zł/rok;

$K_{\text {est }}$ - suma stałych kosztów eksploatacyjnych, zł/rok;

$K_{\text {inpc }}$ - całkowite nakłady inwestycyjne na instalację z pompą ciepła, zł.

Roczne koszty eksploatacyjne zmienne - składowa zmienna kosztów rocznych $K_{e z m}$ obliczono z zależności (11) [9].

$$
K_{e z m}=\frac{Q_{p c} \cdot T_{i p c} \cdot c_{e l} \cdot k_{m r}}{\varphi \cdot \eta_{s i l}}
$$

gdzie: $Q_{p c}-$ moc zainstalowana pompy ciepła, $\mathrm{kW}$;

$T_{i p c}$ - czas użytkowania mocy zainstalowanej pompy ciepła, h/rok;

$c_{e l}$ - cena energii elektrycznej, zł/kWh;

$k_{m r}$ - współczynnik kosztu materiałów ruchowych dla pompy ciepła, -; przyjęto 1,02 według propozycji [9];

$\varphi$ - średni roczny współczynnik wydajności grzejnej, -;

$\eta_{\text {sil }}$ - sprawność silnika elektrycznego napędzającego sprężarkę pompy ciepła, wartość średnia roczna, \%; przyjęto 85\% według propozycji [9].

Koszty roczne wytwarzania ciepła $K_{r p c}$, jako suma składowej stałej i składowej zmiennej, obliczono w oparciu o wzór (12) [9].

$$
K_{r p c}=K_{r s t}+K_{e z m}
$$

Ilość ciepła użytecznego dostarczanego w ciągu roku przez pompę ciepła obliczono z zależności (13) [9].

$$
Q_{a p c}=Q_{p c} \cdot T_{i p c}
$$

Jednostkowy koszt wytwarzanego ciepła $q_{p c}$ jest ilorazem kosztów rocznych i rocznie wytwarzanego ciepła użytecznego, można go określić ze wzoru (14) [9]. 


$$
q_{p c}=\frac{K_{r p c}}{Q_{a p c}}
$$

Wykorzystując zależność (15) obliczono zmniejszenie kosztów uzyskania ciepła $O$ na ogrzewanie powietrza w procesie suszenia skór, za 1 kWh w stosunku do kosztów energii elektrycznej [14].

$$
O=c_{e l}-q_{p c}
$$

Oszczędności możliwe do uzyskania przez użytkownika w wyniku eksploatacji pompy ciepła w przeciągu roku określono ze wzoru (16) [14].

$$
\Delta K=O-Q_{a p c}
$$

gdzie: $O$ - zmniejszenie kosztów uzyskania ciepła na ogrzewanie powietrza w procesie suszenia skór za $1 \mathrm{kWh}$ w stosunku do kosztów energii elektrycznej, zł/kWh,

$Q_{a p c}$ - ilość ciepła użytecznego dostarczona w ciągu roku przez pompę ciepła, $\mathrm{kWh} /$ rok.

Stąd prosty okres zwrotu nakładów SPBT poniesionych na realizację inwestycji można obliczyć z zależności (17) [14].

$$
S P B T=\frac{K_{\text {inpc }}}{\Delta K}
$$

Wyniki obliczeń przeprowadzonej oceny efektywności finansowej inwestycji dla poszczególnych wariantów zestawiono w tabeli 4.

Analiza finansowa metodą kosztów rocznych wykazała jednoznacznie, że ogrzewanie powietrza w procesie suszenia skór, przy użyciu pompy ciepła jest bardziej rentowne w porównaniu do ogrzewania elektrycznego. Wszystkie z rozpatrywanych inwestycji nie tylko umożliwią zwrot nakładów początkowych, ale przyniosą dodatkowo zysk z uwzględnieniem zmiany wartości pieniądza w czasie.

Najefektywniejszym wariantem jest wykorzystanie jako źródła energii niskotemperaturowej przemysłowych ścieków technologicznych powstających w procesie garbowania skór (wariant V). Jednostkowy koszt wytwarzania ciepła $q_{\mathrm{pc}}$ jest w tym przypadku najniższy i wynosi $0,28 \mathrm{zł} / \mathrm{kWh}$ i jest niższy od ceny $1 \mathrm{kWh}$ energii elektrycznej o $0,32 \mathrm{zl} / \mathrm{kWh}$. Jak można zauważyć z danych w tabeli 4, wariant I okazuje się najdroższy w eksploatacji. 
Tabela 4. Zestawienie wyników analizy finansowej

Table 4. Summary of the results of the financial analysis

\begin{tabular}{|c|c|c|c|c|c|}
\hline \multicolumn{6}{|c|}{$\begin{array}{l}\text { Wyniki oceny efektywności finansowej analizowanej inwestycji } \\
\text { dla poszczególnych wariantów }\end{array}$} \\
\hline Wariant obliczeniowy & I & II & III & IV & $\mathrm{V}$ \\
\hline $\begin{array}{l}\text { Rata zwrotu } \\
\text { kapitałowego } r\end{array}$ & \multicolumn{5}{|c|}{0,10} \\
\hline $\begin{array}{l}\text { Rata kosztów stałych } \\
\qquad r+r_{c e}\end{array}$ & \multicolumn{5}{|c|}{0,12} \\
\hline $\begin{array}{l}\text { Roczne koszty stałe } K_{\text {rst }} \\
\text { zł/rok }\end{array}$ & 21503,11 & 16968,86 & 20479,66 & 11042,06 & 11136,91 \\
\hline $\begin{array}{c}\text { Roczne koszty } \\
\text { eksploatacyjne zmienne } \\
K_{\text {ezm }}, \text { zł/rok }\end{array}$ & 23717,35 & 12833,38 & 12833,38 & 13112,36 & 12309,57 \\
\hline $\begin{array}{c}\text { Roczne koszty } \\
\text { wytwarzania ciepła } K_{r p c} \text {, } \\
\text { zł/rok }\end{array}$ & 45220,46 & 29802,24 & 33313,04 & 24154,42 & 23446,48 \\
\hline $\begin{array}{l}\text { Ilość ciepła użytecznego } \\
Q_{a p c}, \mathrm{kWh} / \mathrm{rok}\end{array}$ & 108864 & 82944 & 82944 & 82944 & 82944 \\
\hline $\begin{array}{c}\text { Jednostkowy koszt } \\
\text { wytwarzanego ciepła } q_{p c} \text {, } \\
\text { zł/kWh }\end{array}$ & 0,42 & 0,36 & 0,40 & 0,29 & 0,28 \\
\hline $\begin{array}{c}\text { Zmniejszenie kosztów } \\
\text { uzyskania ciepła } O \text {, } \\
\text { zł/kWh }\end{array}$ & 0,19 & 0,25 & 0,20 & 0,31 & 0,32 \\
\hline $\begin{array}{c}\text { Oszczędności uzyskane } \\
\text { przez użytkownika } \\
\text { w wyniku eksploatacji } \\
\text { pompy ciepła } \Delta K, \text { zł/rok }\end{array}$ & 20751,12 & 20461,82 & 16951,03 & 26109,64 & 26817,59 \\
\hline$S P B T$, lata & 8,43 & 8,55 & 10,32 & 6,70 & 6,52 \\
\hline
\end{tabular}

Obliczenia prostego okresu zwrotu nakładów inwestycyjnych SPBT wykazały, że środki finansowe przewidziane na realizację wariantu IV i V inwestycji najszybciej ulegną zwrotowi bo już po niecałych 7 latach. Przewagą ścieków technologicznych jest ich dostępność, ponieważ są one produktem ubocznym w każdym zakładzie garbarskim, co stwarza korzystne warunki do ich wykorzystania w pompach ciepła, w przeciwieństwie do wód powierzchniowych, do których dostęp może być w wielu przypadkach ograniczony. 


\section{Podsumowanie i wnioski}

W ostatnich latach daje się zauważyć wzrost zainteresowania zakładów garbarskich możliwością wykorzystania odnawialnych źródeł energii. Przeprowadzone badania wykazują, że w polskim przemyśle garbarskim nadal istnieje ogromny potencjał dla wdrażania proekologicznych technologii, mających na celu zmniejszenie zużycia energii. Zwłaszcza, że wykonany przegląd stosowanych dotychczas metod produkcyjnych wykazuje ogromny potencjał działań w zakresie zmian inwestycyjnych. Umożliwiłoby to również nabranie doświadczeń $\mathrm{w}$ bardziej uporządkowanym podejściu do zarządzania środowiskiem, z nastawieniem na redukcję negatywnych oddziaływań na środowisko naturalne.

W klimacie Polski zastosowanie powietrza zewnętrznego jako źródła ciepła do ogrzewania powietrza w procesie suszenia skór jest mało efektywne. W zimie stopień efektywności takiego systemu, przy ujemnych temperaturach na zewnątrz, spada do wartości z zakresu od 2 do 3. Jednocześnie poniżej dolnej granicy zakresu pracy dolnego źródła ciepła pompy ciepła w trybie grzania powietrze zewnętrzne musi być dogrzewane przy użyciu elektrycznej nagrzewnicy powietrza, co w analizie finansowej metodą kosztów rocznych nie zostało ujęte.

Reasumując, można stwierdzić, że wykorzystanie energii cieplnej z przemysłowych ścieków technologicznych, jako odpadowego źródła ciepła w zakładach garbarskich, jest zarówno technicznie możliwe, ale również opłacalne finansowo. Należy zaznaczyć, że ściekowy wymiennik ciepła w postaci klatek energetycznych umieszczonych $\mathrm{w}$ zbiorniku na ścieki jest stosunkowo tani i prosty w montażu w odniesieniu do wymienników gruntowych, a może przynieść znaczne oszczędności energii.

Przedstawione w niniejszym artykule wyniki obliczeń efektywności finansowej zastosowania systemów ogrzewania powietrza w procesie suszenia skór z uwzględnieniem różnych dolnych źródeł niskotemperaturowych, uzasadniają celowość ich użycia w celu redukcji ilości zużywanej energii. Wykazano, że najbardziej efektywny pod względem energetycznym i ekonomicznym jest wariant $\mathrm{V}$, w którym jako dolne źródło ciepła wykorzystano przemysłowe ścieki technologiczne. W rozwiązaniu tym jednostkowy koszt wytwarzania ciepła $q_{\mathrm{pc}}$ wynosi $0,28 \mathrm{zz} / \mathrm{kWh}$. Okres zwrotu inwestycji na instalację tego typu okazał się najkrótszy, bowiem wynosi on mniej niż 7 lat.

Zmiana spojrzenia na to medium z produktu ubocznego na atrakcyjne źródło niskotemperaturowe dla pomp ciepła, okazuje się niezwykle rentowne, jak również przyjazne środowisku. Co więcej, jest to zgodne z racjonalną gospodarką energetyczną, która dąży do tego, aby ilość niewykorzystanej energii była minimalizowana. 


\section{Literatura}

[1] Bieńkiewicz K.J.: Fizykochemia wyprawy skór, Wydawnictwa Naukowo -Techniczne, Warszawa 1986.

[2] Czarniecki D., Pisarev V., Dziopak J., Słyś D.: Analiza techniczna i finansowa instalacji do odzysku ciepła ze ścieków w budynkach wielorodzinnych, Interdyscyplinarne zagadnienia w inżynierii i ochronie środowiska, Wrocław 2014, s. 132148.

[3] Czarniecki D., Słyś D.: Analiza techniczna i finansowa odzysku ciepła odpadowego ze ścieków w miasteczku akademickim Politechniki Rzeszowskiej, Technologia Wody, nr 4, 2015, s. 73-81.

[4] Czarniecki D., Słyś D.: Analiza techniczna i finansowa wariantów ogrzewania wody z wykorzystaniem pomp ciepła współpracujących z systemami rozsączania wody deszczowej w produkcji roślinnej, Czasopismo Inżynierii Lądowej, Środowiska i Architektury, z. 61(3/I), 2014, s. 33-51.

[5] Czarniecki D., Słyś D.: Wykorzystanie wód w instalacjach z pompami ciepła, [w:] Workshop o Vode, Harbulakova V., Zelenakova M., red., Koszyce 2015, s. $10-24$.

[6] Domański W., Surgiewicz J.: Zagrożenia chemiczne w przemyśle garbarskim, Bezpieczeństwo pracy, nr 4, 2001, s. 6-9.

[7] Katalog doboru pomp ciepła firmy Dimplex.

[8] Klepaczewski K.: Źródła substancji rozpuszczonych w ściekach garbarskich oraz ocena możliwości ich ograniczenia, Przegląd Włókienniczy - Włókno Odzież Skóra, nr 11, 2007, s. 25-26.

[9] Kusto Z.: Uwarunkowania ekonomicznej efektywności pomp ciepła, IMP PAN, Gdańsk 2006.

[10] Laskowski P.: Własna elektrownia słoneczna, Murator, nr 2, 2016, s. 126-131.

[11] Lebiediew P.D.: Wymienniki ciepła, urządzenia suszarnicze i chłodnicze, Wydawnictwa Naukowo-Techniczne, Warszawa 1968.

[12] Mendrycka M., Stawarz M.: Zastosowanie biopreparatu wspomagającego oczyszczanie ścieków garbarskich osadem czynnym, Inżynieria Ekologiczna, nr 28, 2012, s. 43-56.

[13] Pawłow K.F., Romankow P.G., Noskow A.A.: Inżynieria chemiczna. Przykłady i zadania z zakresu aparatury i inżynierii chemicznej, Wydawnictwa Naukowo -Techniczne, Warszawa 1963.

[14] Pisarev V.: Projektowanie instalacji grzewczych z pompami ciepła, Oficyna Wydawnicza Politechniki Rzeszowskiej, Rzeszów 2013.

[15] PN-76/B-03420: Wentylacja i klimatyzacja. Parametry obliczeniowe powietrza zewnętrznego.

[16] Religa P., Gierycz P.: Układy membranowe do oczyszczania toksycznych ścieków garbarskich, Przegląd Włókienniczy - Włókno Odzież Skóra, nr 10, 2010, s. 33-37. 
[17] Religa P., Żarłok J., Sobczak A., Gierycz P., Cichy M. J.: Perspektywy wdrażania czystych technologii w polskich garbarniach. Cz. II, Przegląd włókienniczy, nr 1, 2010, s. 31-33.

[18] Rodziewicz O.: Podstawy technologii garbarstwa, Wyższa Szkoła Inżynierska, Radom 1984.

[19] Rubik M.: Pompy ciepła. Poradnik, Ośrodek Informacji: „Technika instalacyjna w budownictwie", Warszawa 2000.

[20] Słyś D., Kordana S.: Odzysk ciepła odpadowego w instalacjach i systemach kanalizacyjnych, Wydawnictwo i Handel Książkami „KaBe”, Krosno 2013.

[21] Stec A., Słyś D.: Instalacje ekologiczne w budownictwie mieszkaniowym, Wydawnictwo i Handel Książkami „KaBe”, Krosno 2016.

[22] Strumiłło C.: Podstawy teorii i techniki suszenia, Wydawnictwa Naukowo -Techniczne, Warszawa 1975.

[23] System kolektorów gruntowych Uponor. Poradnik techniczny; 2012.

[24] Szuba P.: Ścieki garbarskie i kuśnierskie na Podhalu, Forum Eksploatatora, nr 4, 2009, s. 44-48.

[25] Trznadel B. J.: Zastosowanie pras filtracyjno-odwadniających typu SALSNES FILTER do oczyszczania ścieków garbarskich, Przegląd Włókienniczy - Włókno Odzież Skóra, nr 2, 2005, s. 73-76.

\section{TECHNICAL AND FINANCIAL ANALYSIS OF AIR HEATING SYSTEM IN THE DRYING PROCESS USING HEAT PUMP WITH THE USE OF VARIOUS LOWER HEAT SOURCES}

\section{S u m m a r y}

Animal skin is of one of the first materials used by man. Initially, the skin was used in unprocessed form. Moisture, mold and bacteria resulted in the rapid destruction of the articles made from the untreated leather. Over the years, men have learned how to extend the life, increase the mechanical strength and increase the aesthetic value of the skin. Tanned skin has become a versatile material of great importance for the development of civilization. Leather hunted animals were made primarily objects of everyday use, i.e. shoes, clothing, bags, tents, harnesses for draft animals, books, pieces of armor and weapons, etc. With the development of technical skin was becoming more widely used. In the last century, one can observe a tendency to displace the skin as technical material for rubber, plastics and artificial leather. Global trends indicate, however, that tanned skin for a long time will be a luxury and sought after material for the production of shoes, garments, leather products, etc. Understanding and mastering the tanning process has opened the leather products in daily life. The technique tanning of the skin is extremely complex, composed of a plurality of processes and processing operations, in which a very important role fully drying. The purpose of this article is to compare the system of alternative sources of energy by using heat pumps to heat supply air heater for drying skins. Multivariate analysis was carried out technical and financial assistance of these systems at fixed conditions. Installation for drying tunnel were analyzed for five variants.

Keywords: heat pump, lower heat source, ground heat exchanger, waste heat, tannery waste water 
DOI: $10.7862 / \mathrm{rb} .2016 .150$

Przestano do redakcji: 01.05.2016 $r$.

Przyjęto do druku: 28.06.2016 r. 